\title{
Legal Protection for Consumers on Unlabelled Processed Food from Seaweed in Brebes Regency
}

\author{
Dwi Edi Wibowo ${ }^{1 *}$, and Benny Diah Madusari² \\ ${ }^{1}$ Faculty of Law, Universitas Pekalongan, 51115, Indonesia \\ ${ }^{2}$ Faculty of Economic, Universitas Pekalongan, 51115, Indonesia
}

\begin{abstract}
Some certain types of seaweed, such as Euchema, Cottoni, Gracelaria, are also cultivated by people who live at coastal areas in Java. They make seaweed as a processed food like candies and solid porridge (dodol) because seaweed contains many nutrient substances, such as water $(27,8 \%)$, protein $(5,4 \%)$, carbohydrate $(33,3 \%)$, fat $(8,6 \%)$, coarse fiber $(3 \%)$ and ashes $(22,25 \%)$. Government should convince or guarantee with legal certainties, that people who consume goods and services, especially food products are safe, so that the existing of Rules as well as the regulations and other law for products set up and launched by the government, for giving protection to the people who use or consume the goods and products, will possibly bring a sense of security and improve welfare. The question is how is the legal protection for consumers on unlabelled processed food from seaweed? The Approach method used is empirical-juridical method which is used to solve problems by conducting research on primary data in the field. Juridical itself is a kind of research method referring to the law, the currently in force laws and regulations, and the theory of law. The regulations used in this research are Regulation No 8 / 1999 concerning Customers' protection that is Regulation No.18 / 2012 concerning food.
\end{abstract}

\section{Introduction and Literary Review}

Refering to the Opening of the Fourth Paragraph of the Republic of Indonesia's Constitution, that Indonesia's national development is aimed to improve the welfare of the Indonesian people, both physically and spiritually, by convincing people that clothing, food, and housing as the basic needs, should be adequated and fulfilled.

The rapid development of economic has resulted various kinds of goods and services which people can consume or buy. Government should convince or guarantee, with legal certainties, that people who consume goods and services, especially food products are safe, so that the existing of Rules as well as the regulations and other law for products set up and launched by the government, for giving protection to the people who use or consume the goods and products, will possibly bring a sense of security and improve welfare. The legal

\footnotetext{
* Corresponding Author: dwiediwibowo73@yahoo.co.id
} 
certainties will be possibly found out from the existing of the products of law that give protection to Indonesian people when using or consuming goods, especially food [1].

Food is one of the basic needs for all levels of people as well as clothing and housing. Food is the basic need for human being to survive. The regulation no 18 / 2012 concerning food, states that food is the basic need and should be fulfilled because it is part of human rights protected by Republic of Indonesia's constitution 1945, as the basic component to produce qualified human resources. No one can deny that every living thing, including human being needs food, that is the reason why most of people runs food businesses or produces any kinds of food. However, the development in goods and services industry has possitive side, for example the need for good-quality products and the alternative products for all kinds of consumers is always available in sufficient quantities. On the other hand, it brings out the negative sides, especially for the attitude of business actors. As the competition becomes tight, the entrepreneurs or business owners will do anything to get more and more profit without considering the safety and comfort for the customers who consume their products, including in food products [2].

The potential area for the seaweed ponds in Brebes regency is 12.748 hectares, and only about 4.350 hectares that have been used for seaweed cultivation. The potential of the dried seaweed harvest is 2.175 tons, while the market demand is 1.700 tons per-month (DKP Brebes, 2016). The fact above shows that yields produced by the group of seaweed cultivators is only 200 tons so that the amount available is still far from the potential numbers of seaweed ponds. It means that the opportunity to develop the result of seaweed harvest is still wide open.

The processed-seaweed business, as other agricultural-based businesses, takes the close linkages between upstream and downstream. This is due to the upstream (cultivators) has the skill and the will in making production, but not having the access to market and required technology. Meanwhile, the downstream (processors) has the power to access market and technology, but requires the continuity in availability of raw materials.

In order to provide comfort and safety to the consumers, the processed food from seaweed takes healthy business activity and good processing from the raw Seaweed Industry Center in Randusanga Village, Brebes. It is one of the arrangements of five industrial centers in Brebes Regency. The Department of Industry and Trade of Brebes Regency has chosen or determined to develop seaweed as one of the people's favorite commodity in Randusanga Village, Brebes, because of the economic potentials, the workforce development, and the convenience which is really potential for the seeweed-industrial-cluster development in Brebes regency such as jelly, seeweed solid porridge, seaweed cendol, and materials to 'ready-to-consume' products. The point is the consumers should be granted a guaranteed protection of consumer for all the products they consume or buy [3].

\subsection{Definition of food}

According to the rules chapter 1, number (1) of the regulation no 7 / 1996 concerning food (UUP), that Food is everything that comes from biological sources or water, which is processed or not processed, both as food or drinks for human beings, including food additives, food raw materials, and other materials which is used in preparing, processing, and also in producing food and drinks.

\subsection{Types of food}

a. Fresh food is a type of food which can be consumed right away or directly without being processed, and can be used as raw material in food processing, for example, rice, fresh fruits, fish, fresh water. 
Certain processed food is a kind of processed food which is addressed to certain groups in attempting to maintain and develop the group's quality of health.

b. Fast food

Fast Food is food or drinks which has been processed and can be directly served inside or outside the business places based on the consumer's order.

\subsection{Food Product Category}

Indonesia has such an incredible wealth of food with potential natural resources which can be processed and developed to be many kinds of food. There are various kinds of food products which have been categorized by the government through an authorized institution called BPOM (Badan Pengawas Obat dan makanan or Food and Drugs Assosciation).

According to the decision of the head of Indonesia's Drug and Food Administration no HK. 00.05.52.4040, concerning food category. that Food is divided into 12 categories as follows [4]:

1. Milk and its analog, except no 2

2. Fat, oil, and emulsion of oil

3. Eaten ice

4. Fruit and vegetables

5. Candies and chocolate

6. Cereal and all cereal products which are derivatives of cereal seeds, roots and tubers, beans and pith, not including bacterial products from the category no.7 and peanuts from the category no. 4

7. Bacterial products

8. Meat and meat products, including poultry meat and meat of hunted animals

9. Fish and fishery products including mollusks, crustaceans, echinoderms, and amphibians and reptiles

10. Eggs and egg products

11. Sweeteners including honey

12. Salt, spices, soups, sauces, protein products

\subsection{Definition of Legal Protection}

Legal protection is to provide a protection for human rights that are harmed by others and it is given to the community so that they can own or enjoy all the rights granted by the law. In other words, legal protection is a variety of legal remedies that must be provided by the law enforcement officers to afford a sense of security, both in mind and physical from interference and various threats from any party.

\subsection{Definition of Consumers}

According to the Consumer Protection Act (UUPK), "Consumer is every person who uses goods or services available in the community, for him/herself, family, other people, and other living things, not for trading.

\section{Objective of the Study}

The purpose of this study is to find out how legal protection, for consumers against the unlabeled processed food from seaweed in Brebes Regency. 


\section{Methodology}

This research was conducted by using an empirical-juridical method. This approach method is used to solve problems by conducting research on primary data on fiel. The Juridical itself is a research method that adheres to the law, the currently in force laws and regulations, the legal theory, and the opinions of law graduates. The legislation used in this study includes Law Number 8 of 1999 concerning Consumer Protection and Law Number 18 of 2012 concerning Food. While empirical, means that this law writing aims to obtain empirical knowledge about the relations and the influence of law as a tool to regulate the community by conducting direct research on the subject. That's why the data obtained in this empirical approach is primary data which was obtained directly through interviews. Specifications used in this research is descriptive and analytical. Descriptive means to provide a detailed and comprehensive description regarding consumer protection on unlabeled food processing from seaweed based on the currently in force legislation. While analysis has the intention to connect, compare and explain consumer protection on unlabeled food processing from seaweed. Data collection method in this study is to collect secondary data. Secondary data is data obtained using literature study [5].

\section{Discussion}

\subsection{Consumer Legal Protection on Unlabeled Processed Food from Seaweed in Brebes Regency}

The products of seaweed processed food which are existing or circulating on the market should pass the circulation feasibility process at BPOM to ensure that the processed food is safe and comfortable for consumer consumption and can be traded. In Indonesia, processed food products are regulated by the following legislation:

\subsubsection{Law Number 8 of 1999 concerning Consumer Protection.}

Law Number 8 of 1999 concerning Consumer Protection provides protection for every consumer who feels harmed by business people. Article 8 paragraph (1) and paragraph (3) of Law Number 8 of 1999 concerning Consumer Protection regulates the acts that are prohibited to be done by business people, such as:

a. (The product or services) does not meet or does not comply with the required standards and regulations;

b. No label or No explanation of the item which contains the name of the item, size, weight / net or net content, composition, rules of use, date of manufacture, side effects, name and address of the business owner/actor;

c. Does not include information or instructions in Indonesian language, on the use of goods in accordance with the currently in force laws and regulations.

Because of the establishment of these laws and regulations, there will be sanctions/penalties given for every violation that occurs, as written in Article 19 of Act No.8 of 1999 concerning Consumer Protection [7]:

a. Business owners/actors should responsible to give compensation for damages, pollutions, or loss, due to consuming goods or services they produce or trade.

b. The compensation as written on paragraph (1) could be in the form of refund, replacement of goods or similar services or equivalent in value, a health care, or other compensation in accordance with the currenly-in-force laws and regulations 
c. The Submission of the compensation should be carried out within a period of seven days after the date of transaction.

d. The Submission of the compensation as written on paragraph (1) and (2) will not eliminate the possibility of criminal prosecution based on the element of error found after further verification. The provisions as written on paragraph (1) and paragraph (2) will not be applied if the business actor can prove that the mistake is a consumer error [6].

\subsubsection{Law Number 18 of 2012 concerning Food}

In Article 1 paragraph (5) of the provisions of Law No.18 / 2012 concerning Food stated that: Food Safety is a required condition and efforts which are done to prevent food from possible biological or chemical contamination, and other things which could possibly interfere, harm and endanger human health, and not contrary to the religion, beliefs and culture of the community. This convinces that the food is safe for consumption. This arrangement has such a big impact to consumer safety in using food products because it has covered all aspects of consumer life, including things that harm both in terms of health, belief and religion. As the result, we can say that Law Number 18 of 2012 concerning Food, especially in Article 1 paragraph (5) has become a part of bases concerning consumer protection.

\subsubsection{Law Number 36 / 2009 concerning Health.}

Food processed products from seaweed that contain hazardous ingredients are not suitable products for consumption because they can, not only harmful to health but also endanger life. These food products cannot be distributed because the quality and safety are not guaranteed as determined by the authorized agency (BPOM). It is stated in article 109 and article 111 paragraph (1) of Law Number 36 of 2009 concerning Health about doing protection for food and beverages containing hazardous ingredients [7].

\subsection{Roles of Government in Overseeing Circulation of Foods Containing Hazardous Ingredients}

\subsubsection{Food and Drugs Assosiaciation (BPOM)}

$B P O M$ is the institution which is responsible for overseeing the circulation of food and drugs in Indonesia in accordance with the currently in force laws and regulations. According to article 67 of Presidential Decree Number 103 of 2001, which states that BPOM carries out government duties in the field of food and drug supervision in accordance with the currently in force laws and regulations.

According to Presidential Decree Number 103 of 2001 that supervision of food products containing hazardous ingredients becomes the responsibility of the Food and Drug Administration.

The supervision carried out by the Food and Drug Administration consists of:

a. Pre Market Control

Before food and drugs are allowed to be produced, imported and distributed in Indonesia, BPOM will conduct a serial evaluation to assess the safety, quality, usefulness and label / product information.

b. Post Market Control 
After the product launched to the market, BPOM will do inspection to industrial / production facilities and regularly checking the product availability in market.

\subsubsection{Department of Industry and Commerce}

The main task in doing consumer protection and supervision of product circulation is to carry out the preparation for formulating the technical policy, coaching and implementing the consumer protection, supervising the circulation of goods and services, including supervising the metrological things.

\section{Conclusion}

Law Number 8 of 1999 which emphasizes the honesty of business people in running their business by not endangering the health of consumers. Sanctions, as well as imprisonment, are compensation according to the amount or form of compensation should be agreed by both parties. Law Number 18 of 2012 concerning Food which requires the use of food additives, which is safe for health, the sanctions will be imprisonment sanctions, revocation of certain rights, and the announcement of a judge's decision. Law Number 36 of 2009 which states that business actors should guarantee the consumers' comfort and safety of in consuming their products.

The sanctions that follow are the products will be prohibited and withdrawn from circulation, revoked the circulation permits and confiscated for destruction. Consumer protection is also supported by the government by establishing a government agency engaged in supervising and doing the regulation of food distribution.

\section{References}

1 S. Hudaidah, Plankton Composition in Plastic Ponds, Study of Plankton Composition in White Shrimp Cultivation (Litopenaeus vannamei) in Plastic ponds, Research Report, Lampung University (2009)

2 S. Sulaeman, Infokop, 28, 72 (2006)

3 B. Madusari, Profile of Seaweed Agribusiness in Pekalongan City. Cooperation with BPPT Pekalongan City, (2013)

4 S. Sulaeman, Infokop 28, 78 (2012)

5 R. H. Soemitro, Methodology of Legal Research and Jurimetry, (Ghalia, Jakarta, 2010)

6 Law Number 8 of 1999 concerning Consumer Protection

7 Law Number 18 of 2012 concerning Food 